\title{
Variante -174 G>C do gene IL6 associada à suscetibilidade à migrânea
}

\author{
Debora Villas Boas Rezende (D), Bárbara Ferreira Khouri (D), Ana Paula Gallina Pezzini (iD, Maria Eduarda Ajita (D), \\ Valéria Aparecida Bello (iD, Regina Célia Poli Frederico iD, Aline Vitali da Silva (iD
}

Pontifícia Universidade Católica do Paraná, Curitiba, Paraná, Brasil

\author{
Introdução \\ A migrânea é uma cefaleia primária, cuja fisiopatologia está relacionada a secreção do peptídeo CGRP e a infla- \\ mação neurogênica.
}

\section{Objetivos}

Analisar a influência das variantes do gene IL6-174 G>C e -597 G>A na suscetibilidade e parâmetros clínicos da migrânea.

\begin{abstract}
Material E Métodos
Trata-se de um estudo prospectivo observacional do tipo caso-controle, composto por 92 participantes, sendo 44 pacientes com migrânea e 48 controles saudáveis, pareados para sexo, idade, etnia e IMC. O projeto foi aprovado pelo Comitê de Ética em Pesquisa, $n^{\circ} 98316718.7 .0000 .0020$. Foram realizadas entrevistas estruturadas e obtidos dados demográficos, clínicos, antropométricos e relacionados à migrânea e suas características. Os participantes responderam aos questionários validados referentes a incapacidade da migrânea (MIDAS) e alodinia (ASC-12). O DNA foi obtido por extração de leucócitos do sangue periférico e material da mucosa oral. As genotipagens foram feitas por PCR-SSP. Para determinar a suscetibilidade à migrânea, foi realizada regressão logística binária e, para análise das características clínicas, o teste de Qui-quadrado e Mann Whitney. Foi considerada diferença estatística quando $p \leq 0,05$.
\end{abstract}

\section{Resultados}

Indivíduos com o genótipo CC da variante-174 G>C, menor produtor da citocina pró-inflamatória, apresentaram menor suscetibilidade à migrânea, quando comparados a indivíduos com o genótipo GG ou GC no modelo recessivo $(O R=0,14 ; p=0,026)$. Não houve influência da variante $-597 \mathrm{G}>\mathrm{A}$ na suscetibilidade à migrânea. Ambas as variantes não demonstraram associação com a forma episódica ou crônica, presença de aura, pósdromo, pródromo, fonofobia, fotofobia, osmofobia, incapacidade e alodinia. Contudo, este resultado pode ter sido limitado pelo pequeno número amostral.

\section{Conclusões}

O genótipo CC da variante -174 G>C do gene IL6 demonstrou exercer efeito protetor ao desenvolvimento da migrânea, com chance $86 \%$ menor de migrânea quando comparado aos genótipos GG ou GC.

Palavras-chave: Migrânea, Interleucina-6, Variante genética. 